\title{
The Effect of the Size of Public Accounting Firm, Leverage, and Corporate Governance on the Integrity of Financial Statement: A Study on Companies Listed on Indonesian Stock Exchange
}

\section{Qurrota A'yunin, | Gusti Ketut Agung Ulupui, and Marsellisa Nindito}

Faculty of Economics, Universitas Negeri Jakarta, Jakarta, Indonesia

\section{Abstract}

This research was conducted to find out how the size of the Public Accounting Firm (KAP), leverage, and corporate governance affect the integrity of financial statements of companies listed in the Indonesia Stock Exchange (IDX) and indexed in the Corporate Governance Perception Index (CGPI). The research covers a period of 5 years' data observation (2012-2016). The effect of KAP size, leverage, and corporate governance were tested by applying panel data regression analysis. The result shows that leverage has a negative significant effect on the integrity of financial statements. However, the size of KAP and corporate governance have no significant effect on the integrity of financial statements.

Keywords: size of KAP, leverage, corporate governance, integrity of financial statement, corporate governance perception index

\section{Introduction}

permits unrestricted use and redistribution provided that the original author and source are credited.

Selection and Peer-review under the responsibility of the $3 \mathrm{rd}$ ICEEBA Conference Committee.

\section{G OPEN ACCESS}

The increasing development of advanced technology such as the internet, the development of systems and the use of websites in businesses has strongly benefited shareholders as well as stakeholders to have an open access to information of the company's financial statements. Financial statement has a very important role in the process of measuring and evaluating the performance of a company. The Indonesian Institute of Accountants (2017) stated in the Financial Reporting Conceptual Framework (KKPK) in the Statement of Financial Accounting Standards (PSAK) that the purpose of the financial statements is to provide financial information about reporting entities that are useful for current investors and potential investors, lenders, creditors and others in making decisions process. Given the importance of financial statements for stakeholders, the financial statements must be reliable. However, in many cases show that company's 
financial statements prepared do not actually reflect the actual conditions of companies. This can be seen from the emergence of various cases of accounting fraud. The occurrence of irregularities in financial statements triggers an indication of financial report manipulation. It means that it is possibile that companies with good reputation in the industry may involved in cases of financial statement fraud. Therefore, this research is done to study further the integrity of financial statements of companies listed in IDX dan provide the empirical evidence on the integrity of financial statements that is measured by conservatism approach using the accrual size approach. The purpose of this research is to find out the effect of the size of the Public Accounting Firm (KAP), leverage, and corporate governance on the integrity of financial statements.

\section{Theoritical Review and Hipotheses Development}

\subsection{Agency theory}

Agency Theory refers to agency relations between the owner (principal) who gives the mandate to the management (agent). Jensen and Meckling (1976) describe agency relationships as "agency relationships as a contract under which one or more people (the principals) engage another person (the agent) to perform some service on their behalf". Which means that the agency relationship is a contract whereby one or more people (principals) order another person (agent) to carry out a service on behalf of the principal and authorize the agent to make the best decision for the principal.

\subsection{The integrity of financial statement}

Kieso (2011) stated that the statement of financial accounting concept (SFAC) No. 2 on qualitatitve characteristic of accounting information stated that there are two primary qualities in a financial statement which are relevance and reliability. Thus, the integrity of financial statements is an accounting information that can be relied upon with an honest, precise and impartial presentation to enable users of accounting information to depend on the information and have the ability to influence the decisions of users of financial statements to make decisions. Intuitively, the measurement of the integrity of financial statements is divided into two ways, namely through conservatism and the existence of financial statement manipulation which is generally measured by earnings management (Mayangsari, 2003; Rozania, et al 2013). In this study, the measurement of 
the integrity of the company's financial statements applies the conservatism measurements. Conservatism in the Statement of Concepts No. 2 FASB is defined as the principle of prudence in responding to uncertainty by ensuring that business uncertainty and risk are adequately considered. "A prudent reaction to uncertainty to try to ensure that uncertainties and risks inherent in business situations are adequately considered ". Accounting conservatism is considered as reaction that shows caution in anticipating future uncertainty. Beaver and Ryan (2000) applies models that shows if the market to book value is higher, the company is declared to be more conservative, which means that the company has more integrity. This study refers to Nurdiniah and Pradika (2017) which also measure the integrity of financial statements with the conservatism model developed by Beaver and Ryan (2000).

\subsection{The size of public accounting firm (KAP)}

KAPs can be divided into large-scale and small-scale of KAPs (Table 1). DeAngelo (1981) stated that large-scale auditors have more incentives to avoid reputation damage than small-scale auditors. Large-scale auditors also tend to reveal existing problems in company's financial statements because they are more powerful in facing litigation risks. Currently many Indonesian KAPs have cooperated with Foreign KAP or Foreign Accountant Organizations as listed in the Institute of Indonesian Public Accountants directory. The existence of such international cooperation for Indonesian KAP can have a direct effect on audit quality because of the transfer of knowledge and as a result $f$ the well-kown reputdation. The size of the KAP, the type of client, and the type of international relations will form the characteristics of the work environment for each KAP group, so that it will affect audit quality.

TABLE 1: Number of small, medium, and large KAP in the last five years. (Source: Mustofa, 2014.)

\begin{tabular}{|l|c|c|c|c|c|}
\hline & $\mathbf{2 0 1 0}$ & $\mathbf{2 0 1 1}$ & $\mathbf{2 0 1 2}$ & $\mathbf{2 0 1 3}$ & $\mathbf{2 0 1 4}$ \\
\hline Large KAP $(>=10$ partners $)$ & 4 & 6 & 8 & 10 & 10 \\
\hline Medium KAP $(4-9$ partners $)$ & 20 & 24 & 25 & 30 & 36 \\
\hline Small KAP $(1-3$ partners $)$ & 478 & 474 & 442 & 449 & 427 \\
\hline
\end{tabular}

\subsection{Leverage}

Leverage is the proportion of total debt used to provide an overview of the capital structure of the company so that it can be seen the level of risk of uncollectible debt. Leverage shows the proportion of funding companies that are financed by debt. The higher 
the leverage of a company means the higher the dependence of the company to its creditors. This is consistent with agency theory, namely the agency relationship between the principal and the agent. The company will try to provide a large information about the condition of the company for the understanding of the creditors for credit decision making process. Fajaryani (2015) stated that the existence of debt is measured by financial ratios, namely leverage. Companies with a high level of leverage will negatively affect the level of integrity of financial statements due to increased risk associated with debt agreements.

\subsection{Corporate governance}

Corporate Governance is the system of controls, regulations, and incentives designed to prevent fraud (Berk and DeMarzo, 2011). Corporate governance is a system that is the basis of a process, a mechanism in managing a company that is good based on regulations, legislation and ethics trying to create trust in the company by creating a healthy business climate that can increase the company's added value in the long term as well as accountability to stakeholders interests (stakeholders) (Putri and Ulupui, 2017: 4). The Corporate Governance Perception Index (CGPI) is a research program that rank the implementation of good corporate governance (GCG) in companies in Indonesia through certain design of research. It encourages companies to improve the quality of the implementation of corporate governance (CG) concepts by conducting evaluation and benchmarking as a continuous improvement effort CGPI has been organized by IICG in collaboration with SWA Magazine as a regular annual program since 2001 as a form of appreciation for the initiative and company's efforts to realize an ethical and dignified business.

\section{Theoretical Framework}

Based on the conceptual description and the results of several relevant previous studies, the thinking framework of this research can be described as follows:

The Agency Theory explains that financial statements should be presented reliably and relevant so that they can be useful in decision making especially for stakeholders. The integrity of the financial statements will reflect the integrity of the company's management, so that it will improve stakeholders' trust on the company's capabilities and the company's future performance. The existence of auditors who audit company reports will make the financial statements have a quality that can be accounted 


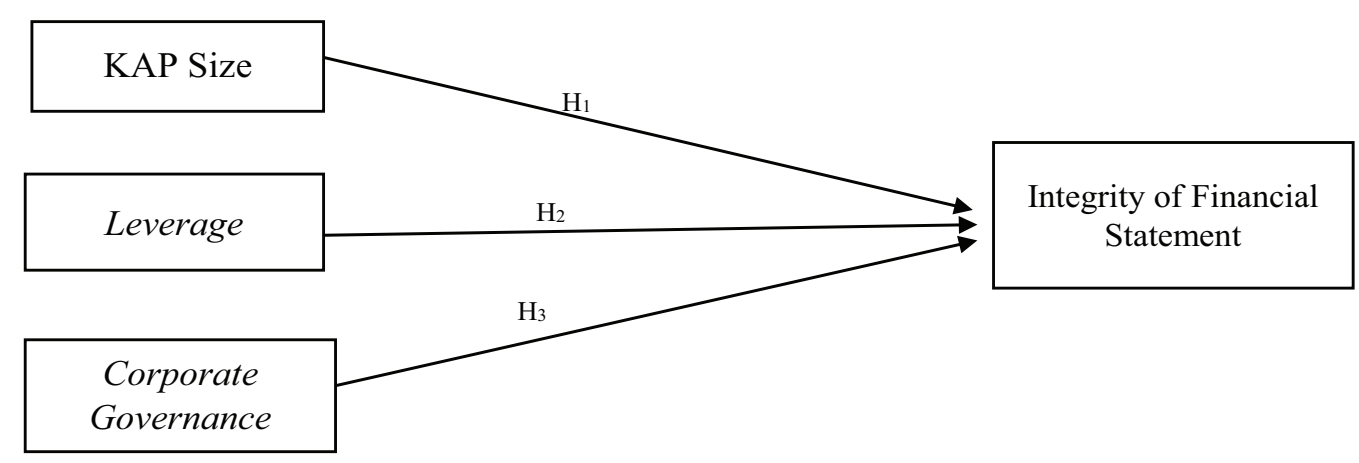

Figure 1: Theoretical Framework. (Source: Researchers, 2018.)

for. Agency theory states that there is a separation between principals as owners and agents as managers who run the company, there will be agency conflicts. This is because, each party will always try to maximize its utility functions for the benefit of each individual, so this raises the motive of the manager to commit accounting fraud through manipulation of financial statements so that the information shown in the financial statements regarding the condition of the company still looks good and interesting. Because the emergence of agency conflicts from the different interests of each individual between the principal and the agent will lead to a decline in the integrity of the company's financial statements because the information presented is not reliable anymore.

\subsection{The onfluence of the size of KAP on the integrity of financial statement}

To increase the confidence of users of financial statements on the credibility of financial statement, it must be complemented with an independent audit report issued by the Public Accounting Firm (KAP). Therefore, company's financial statement must be audited by auditors with strong competence and independence. It is necessary to provide assurance that the financial statements are free from material misstatement and integrity that can be accounted for. Nurdiniah and Pradika (2017) showed that there is positive significant effect of KAP reputation on the integrity of financial statements. 


\subsection{The influence of leverage on the integrity of financial statement}

Fajaryani (2015) said that leverage ratio is the ratio used to measure the extent to which a company's assets are financed by debt. Companies that have a high level of leverage will show that the company has too high financial risk. This is because the company is experiencing financial difficulties that can be seen how much debt is used to finance company activities. This is what will make the company to disclose more information far from companies with a low level of leverage. But the risks faced by investors will increase so they will demand to get great returns on their investment. This condition is feared to trigger management to do window dressing on financial statements so that integrity is weak. In the study Fajaryani (2015) showed that leverage has a significant influence on the negative direction of the integrity of financial statements, which means that the greater the leverage of the company, the lower the value of financial report integrity, the results of Fajaryani (2015).

\subsection{The influence of corporate governance on the integrity of financial statement}

Gayatri and Suputra (2013) stated that the implementation of good corporate governance will prevent companies from agency conflicts. Jason \& Meckling (1976) stated that there are two forms of agency relationships, which are the relationship between managers and shareholders and the relationship between the manager and the bondholders. The Corporate GovernancePerception Index (CGPI) lists trusted companies that implement corporate governance. It ranks companies from the top to the bottom rank. The higher the rating of the company means that the higher the level of trust value. It shows positive signal for the company which can increase investor confidence in the company dan can affect the value of the company's equity. According to Wdiatmoko, et al (2017), CGPI has a positive significant effect on the integrity of financial statements.

\section{Research Methods}

This study uses a quantitative method using panel data analysis method, as it comprises of several companies (cross section) in several period (time series). Data that has been collected and collected will be processed using Econometric Views (E-Views) version 9 and theories to provide an overview of the object under study and conclusions drawn from the results obtained. 


\subsection{Population and sample}

The population in this study are all companies listed on the Indonesia Stock Exchange (IDX) and indexed in the Corporate Governance Perception Index (CGPI) during the period 2012-2016. Data is collected from financial statements obtained from the website www.idx.co.id. The CGPI report are obtained from the Indonesian Institute for Corporate Governance (CGPI). This research period includes data in 2012-2016 to reflect current conditions. The sampling technique applied is purposive sampling using these following criteria:

1. Companies listed on the Indonesia Stock Exchange (IDX), respectively and participated in the Corporate Governanace Perception Index (CGPI) program for the period 2012-2016.

2. Companies that publish audited financial statements for the period 2012-2016.

3. Financial reports are published in rupiah and have all information needed in this research.

The data used in this study are secondary data in the form of financial position reports, income statements, Corporate Governance Perception Index (CGPI) reports, and Directory of Public Accountants and Public Accountants. Secondary data is data obtained through media intermediaries and this data can generally be directly obtained because it is available in the form of books, records, and published archives. The sources of data in this study are as follows:

\subsection{Operationalization of research variables}

\subsubsection{Dependent variables (The integrity of financial statement)}

The integrity of financial statements is reliable information in a form of an honest, precise and impartial presentation to be used by user of accounting information in decision making process. This study measures the integrity of financial statements using the market to book ratio value developed by Beaver and Ryan (2000) that said that when the market to book ratio is low, the financial statement will be classified as conservative, and vice versa. The formula to calculate market to book value is as follows:

$$
\text { Market to book (MTB) ratio }=\frac{\text { Market value of common equity }}{\text { Book value equity }}
$$

Market value of common equity: common stock market value at the closing price at the end of the year. 
Book value equity: total equity divided by the ordinary shares outstanding.

\subsubsection{Independent variables}

\subsection{Size of public accounting firm (KAP)}

The Public Accounting Firm (KAP) is a business entity that has obtained permission from the Minister as a forum for Public Accountants in providing their services, can be in the form of a business entity or civil partnership. The size of KAP is the differentiation of KAP into large-scale KAP and small-sized KAP. The existence of this public accountant service is needed to provide assurance that the financial statements are free from material misstatement. The size of the KAP is measured by dividing number of clients with number of professionals (partners and staff) which was also applied by Colbert, et al, 1999 in Sarwoko, 2014. This study specifically uses number of partners of Public Accounting Firms (KAP) during the research year.

TABLE 2: Corporate Governance Perception Index (CGPI) Rating. (Source: The Indonesian Institute for Corporate Governance (IICG).)

\begin{tabular}{l|l} 
Score & Category \\
$85-100$ & Most Trusted \\
$70-84$ & Trusted \\
$55-69$ & Fairly Trusted \\
\hline
\end{tabular}

\subsection{Leverage}

Leverage is the proportion of total debt to the average shareholder equity. This ratio is used to provide an overview of the capital structure of the company which will show the level of risk of uncollectible debt. Leverage shows the proportion of funding companies that are financed by debt. The higher the leverage of a company means the higher the dependence of the company to its creditors. Therefore, companies with a high level of leverage will tend to report high profits in order to reduce the likelihood of companies in violating debt agreements. Leverage of a company can be measured in two ways, namely: debt ratio and debt to equity ratio. Debt ratio measures the total amount of assets financed by the company's creditors. The debt ratio (debt ratio) to measure the percentage of fund assets provided by creditors. This study calculates Leverage using the debt to asset ratio.

$$
\operatorname{Lev}_{\text {it }}=\frac{D_{\text {it }}}{A_{\text {it }}}
$$


$\operatorname{Lev}_{i t}$ : leverage company $i$ in year $t$.

$D_{i t}$ : total debt of company $i$ in year $t$.

$\mathrm{A}_{\mathrm{it}}$ : total assets of company $i$ in year $\mathrm{t}$.

\subsection{Corporate governance}

Corporate Governance is a system that directs and controls the company to ensure that the entity is managed appropriately for the benefit of the owner who is not in the company and reports the economic condition and performance of the entity appropriately Gayatri and Suputra (2013). Therefore, if the better the corporate governance in a company, the integrity of financial statements will most likely be achieved. In this study using the announcement of corporate governance ratings based on Corporate Governance Index (CGPI). The index is an assessment research which is made to assess the application of the corporate governance in certain companies. This measurement has 4 assessment indicators with a weighted percentages that have been determined by the Indonesian Institute for Corporate Governance (IICG) namely self assessment (0.25), completeness of documents $(0.23)$, preparation of papers and presentations $(0.17)$ and observation to the company (0.35). The assessment weight are used as a reference to determine the ranking of the company with the highest score up to the lowest score. The ranking is classified into 3 categories, which are explained in the Table 2 below.

\subsection{Hypothesis testing}

In conducting testing, researchers used the best model selection test, classic assumption test, panel data regression analysis, and hypothesis testing. The results of the tests are as follows:

\subsubsection{Best model selection test}

The selection test of the best model has three regression models namely the common effect model, the fixed effect model, and the random effect model used to determine the suitable regression model in testing this research hypothesis. Determining the best model is done by applying the Redundant test and the Hausman test using Eviews 9. 


\subsubsection{The redudant test}

Redundant test is used to choose between common effect models and fixed effect models. To do the Redundant test, use the test criteria if the probability $>0.05$, the common effect model is chosen, but if the probability $<0.05$ then the fixed effect model is selected. The results of the Redundant test testing are shown in Table 3 as follows:

TABLE 3: Redudant test results. (Source: EViews 9, data processed 2018.)

Redundant Fixed Effects Tests

Equation: Untitled

Test cross-section fixed effects

\begin{tabular}{lrrr}
\hline \hline Effects Test & Statistic & d.f. & Prob. \\
\hline \hline Cross-section F & 4.567984 & $(8,32)$ & 0.0009 \\
Cross-section Chi-square & 33.516476 & 8 & 0.0000 \\
\hline \hline
\end{tabular}

Redundant test results shown in Table 3, it is known that the results of the Redundant test, namely Cross-section Chi-square of 0.0000 is smaller than 0.05 or $p$-value of 0.0000 is smaller than 0.05 . Then Ha was accepted so that the fixed effect model was chosen, then continued with the Hausman test to select the fixed effect model or random effect model as a suitable regression model.

\subsubsection{The Hausman test}

The Hausman test is used to choose between the fixed effect model and the random effect model. In conducting the Hausman test using criteria if the probability $\geq 0.05$, the random effect model is chosen but if the probability is $<0.05$ then the fixed effect model. The test results of the Hausman test are shown in table 4 as follows:

TABLE 4: Hausman test results. (Source: EViews 9, data processed 2018.)

Correlated Random Effects - Hausman Test

Equation: Untitled

Test cross-section random effects

\begin{tabular}{lrrr}
\hline \hline Test Summary & $\begin{array}{l}\text { Chi-Sq. } \\
\text { Statistic }\end{array}$ & Chi-Sq. d.f. & Prob. \\
\hline \hline Cross-section random & 13.109071 & 3 & 0.0044 \\
\hline \hline
\end{tabular}


The results of the Hausman test shown in Table 4, it is known that the results of the Hausman test are random cross-section of 0.0044 smaller than 0.05. Then $\mathrm{Ha}$ is accepted so that the fixed effect model is chosen as the best regression model to use.

\subsection{The classical assumption test}

\subsubsection{The normality test}

The normality test is done to test whether the independent variables and the dependent variables are normally distributed or not. Normality testing in this study uses the jarquebera test which has a probability value of two degrees of freedom. If the probability of the test results is more than 0.05 then the data can be concluded normally distributed. However, the test results are less than 0.05, therefore, it concludes that the data is not normally distributed. The results of the normality test in this study are shown in Figure 2 as follows:

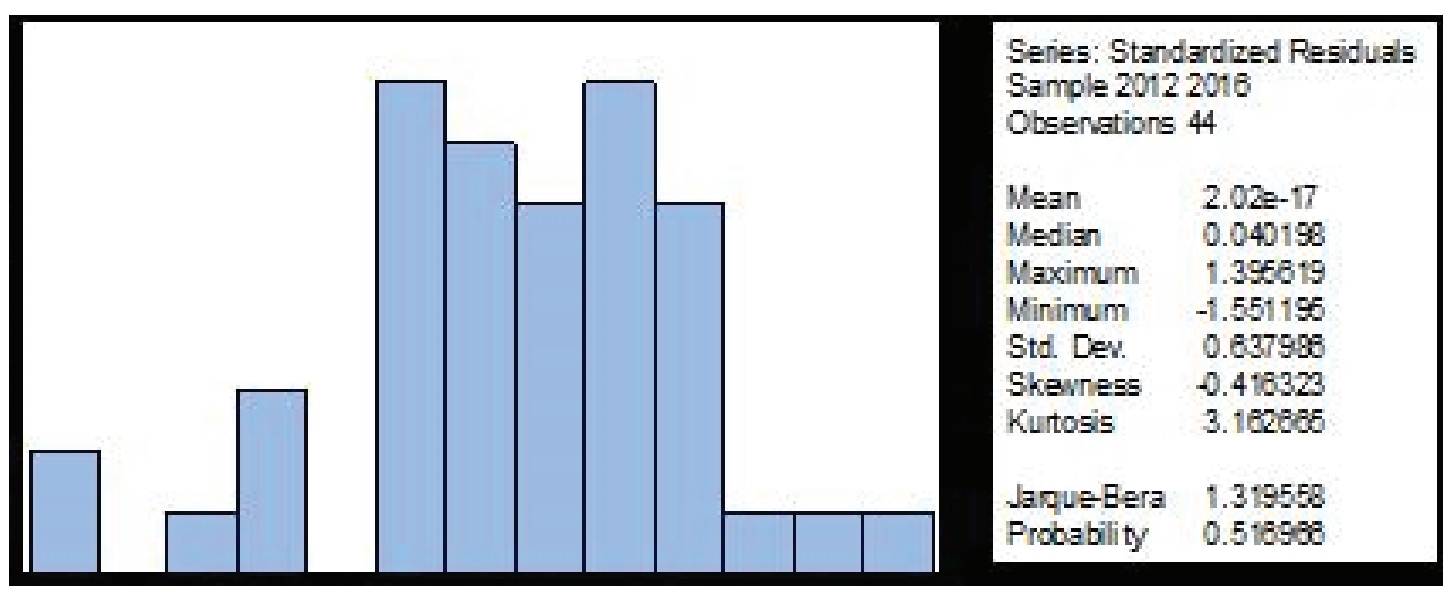

Figure 2: Normallity test result. (Source: EViews 9, data processed 2018.)

Based on the results of the normality test shown in Figure 2, it can be seen that the probability value is greater than 0.05 . it shows that with a results of the probability value of $0.516966>0.05$, it can be concluded that the data is normally distributed.

\subsubsection{The multicollinearity test}

Multicollinearity test was conducted to test whether the regression model found correlation between independent variables. Multicollinearity testing in this study uses observations on the value of Pearson Correlation. If Pearson Correlation has a coefficient value. Multicollinearity test results in this study can be seen in table 5 as follows: 
TABLE 5: Multicollinearity test results. (Source: EViews 9, data processed 2018.)

\begin{tabular}{l|c|c|c|} 
& KAP_SIZE & LEV & CG \\
\hline KAP_SIZE & 1,000000 & $-0,321029$ & $-0,077786$ \\
\hline LEV & $-0,321029$ & 1.000000 & 0.413371 \\
\hline CG & $-0,077786$ & 0.413371 & 1.000000 \\
\hline
\end{tabular}

The test results in table 5 shows that the value of each between variables is smaller than 0.89 . It can be seen that there is no correlation coefficient value greater than 0.89 . Therefore, according to Pearson Correlation testing criteria, it can be concluded that the model in this study is free from multicollinearity.

\subsubsection{The autocorrelation test}

Autocorrelation test aims to test whether the linear regression model contains correlation between confounding errors in period $t$ with confounding errors in period t-1 (previous period). This study uses the Durbin-Watson test to test whether there is autocorrelation. Determination of autocorrelation is observed from the value $d$. The value $\mathrm{d}$ which is located between $\mathrm{dU}$ and $4-\mathrm{dU}$ is concluded that in the model there is no autocorrelation. A value of $d$ smaller than $\mathrm{dL}$ or greater than 4 - $d U$ concludes that in the model there is autocorrelation. The results of autocorrelation testing in this study can be seen in table 6 as follows:

TABLE 6: Autocorrelation test. (Source: EViews 9, data processed 2018.)

\begin{tabular}{lrll}
\hline \hline R-squared & 0.617694 & Mean dependent var & 1.806136 \\
Adjusted R-squared & 0.486277 & S.D. dependent var & 1.031824 \\
S.E. of regression & 0.739555 & Akaike info criterion & 2.461465 \\
Sum squared resid & 17.50213 & Schwarz criterion & 2.948062 \\
Log likelihood & -42.15222 & Hannan-Quinn criter. & 2.641918 \\
F-statistic & 4.700238 & Durbin-Watson stat & 2.220848 \\
Prob(F-statistic) & 0.000286 & & \\
\hline \hline
\end{tabular}

The autocorrelation test results shown by table 6 show the Durbin-Watson value of 2.220848. In this study, it is known that the $\mathrm{dU}$ and 4-dU values are 1.6647 and 2.3353, so that $\mathrm{dU}<\mathrm{d}<4$-dU or $1.6647<2.110501<2.3353$, so it can be concluded that the model does not experience autocorrelation problems. 


\subsubsection{The heterocedasticity test}

Heterocedasticity test is done to test whether in the model there is a variance inequality from residual one observation to another observation. Heterocedasticity testing in this study was carried out by Glejser test by regressing absolute residual values with independent variables and judging from the results of statistical $p$ for each independent variable. If the independent statistic $p$ value exceeds the significance level of 0.05 , then it is free from heteroscedasticity. The results of the Glejser test are in table 7 below.

TABLE 7: Heterocedasticity test results. (Source: EViews 9, data processed 2018.)

\begin{tabular}{|crrrr|}
\hline Variable & Coefficient & Std. Error & t-Statistic & Prob. \\
\hline \hline KAP_SIZE & -0.016875 & 0.012490 & -1.351087 & 0.1861 \\
LEV & -0.645459 & 0.678394 & -0.951451 & 0.3485 \\
CG & -1.870730 & 3.059540 & -0.611442 & 0.5452 \\
C & 2.908204 & 2.608371 & 1.114950 & 0.2732 \\
\hline \hline
\end{tabular}

The heterocedasticity test results shown in table 7 show the significance value of each variable is greater than 0.05 , so it can be concluded that the model in this study is free from heteroscedasticity.

\subsection{Panel data regression analysis}

Regression analysis in this study was conducted to determine whether the relationship between a dependent variable and the independent variables in the regression model. After selecting the best model is the fixed effect, then the results of the panel data regression analysis equation model can be formed which is after doing regression analysis. The regression results in this study are shown in table 8 as follows:

TABLE 8: Regression results of fixed effect model. (Source: EViews 9, data processed 2018.)

\begin{tabular}{|crrrr|}
\hline \hline Variable & Coefficient & Std. Error & t-Statistic & Prob. \\
\hline \hline KAP_SIZE & -0.023760 & 0.026644 & -0.891768 & 0.3792 \\
LEV & -4.824194 & 1.447118 & -3.333656 & 0.0022 \\
CG & 10.39023 & 6.526467 & 1.592014 & 0.1212 \\
C & -3.354543 & 5.564056 & -0.602895 & 0.5508 \\
\hline
\end{tabular}

Based on the regression results above, the panel data regression regression equation used in this study is as follows:

INTGLK $=-3.354543-0.023760 K A P \_S I Z E--4.824194 L E V+10.39023 C G+\epsilon$ 
Where:

INTGLK: Integrity of Financial Statement

KAP_SIZE: KAP Size

LEV: Leverage

CG: Corporate Governance

$\epsilon$ : error standard

\section{Research Results}

\subsection{T-test result}

Testing the significance of individual parameters (Statistical Test $t$ ) is done to see the effect of individual independent variables on the dependent variable. This test is done through probability values. If the probability value is $\leq 0.05$, it can be concluded that the independent variable has a significant effect on the dependent variable. However, if the probability value is $>0.05$, the independent variable has no significant effect on the dependent variable. In addition to the probability value, the effect of the independent variable on the dependent variable can be seen through the value of t. this test is done by comparing $t$ count and $t$ table values. if the value of $t$ count $>t$ table, it can be concluded that the independent variable significantly affects the dependent variable. Conversely, if the value of $t$ arithmetic $<t$ table, then the independent variable can be stated not to affect the dependent variable significantly. With a df value of 40 and a significance of 0.05 , the $t$ table values are 2.02108 for two tail and for 1.68385 one tail. With this testing criterion is if ( $t$ count $>t$ table) or ( $p$-value $<0.05$ ) the independent variable influences the dependent variable. The results of the t-test in this study can be seen through table 9 as follows:

TABLE 9: (Source: EViews 9, data processed 2018.)

\begin{tabular}{|crrrr|}
\hline \hline Variable & Coefficient & Std. Error & t-Statistic & Prob. \\
\hline \hline KAP_SIZE & -0.023760 & 0.026644 & -0.891768 & 0.3792 \\
LEV & -4.824194 & 1.447118 & -3.333656 & 0.0022 \\
CG & 10.39023 & 6.526467 & 1.592014 & 0.1212 \\
C & -3.354543 & 5.564056 & -0.602895 & 0.5508 \\
\hline
\end{tabular}




\subsection{Goodness of fit model test (F-test)}

Statistical test $F$ is done to test the feasibility of the model. This test identifies the regression model that is estimated to be feasible to use in explaining the influence of independent variables on the dependent variable. It is done using the F-statistic Comparison ( $F$ arithmetic) criteria with $F$ table and based on probability $(\rho)$. With a df value of 40 and a significance of 0.05 , the Ftable value is 2.84 . The measurement hypothesis is based on the comparison of the F-statistic value ( $F$ count) to the $F$ table value as follows:

TABLE 10: T-test results. (Source: EViews 9, data processed 2018.)

\begin{tabular}{lrll}
\hline \hline R-squared & 0.617694 & Mean dependent var & 1.806136 \\
Adjusted R-squared & 0.486277 & S.D. dependent var & 1.031824 \\
S.E. of regression & 0.739555 & Akaike info criterion & 2.461465 \\
Sum squared resid & 17.50213 & Schwarz criterion & 2.948062 \\
Log likelihood & -42.15222 & Hannan-Quinn criter. & 2.641918 \\
F-statistic & 4.700238 & Durbin-Watson stat & 2.220848 \\
Prob(F-statistic) & 0.000286 & & \\
\hline \hline
\end{tabular}

Statistical test in this study resulted in a calculated $F$ value of 4.700238 with a significance level of 0.000286 . This shows that the calculated $F$ is greater than $F$ table $(4.700238>2.84)$ with a significance value $(0.000286<0.05)$. The conclusion taken from the Statistical Test $F$ is a regression model worthy to be used in explaining the relationship between independent variables and dependent variables.

\subsection{Coefficient of determination}

The coefficient of determination $\left(R^{2}\right)$ was used to test the ability of the model to explain variations in the dependent variable. Testing the coefficient of determination (R2) was performed using Adjusted R-Squared on the regression equation. Adjusted R-Squared reflects how much changes in the dependent variable can be determined by changes in independent variables. The coefficient of determination is between zero and one. The test results of the coefficient of determination in this study are shown in table 11 below.

Based on the results of the R2 determination test shown in table IV.10 shows the adjusted $\mathrm{R}$ square value of 0.486277 . This means that the ability of independent variables in explaining the dependent variable is 0.486277 . While 0.531723 is explained by other factors outside of regression. Other factors that might affect the dependent 
TABLE 11: The coefficient determination (R2) test results. (Source: EViews 9, data processed 2018.)

\begin{tabular}{lrll}
\hline \hline R-squared & 0.617694 & Mean dependent var & 1.806136 \\
Adjusted R-squared & 0.486277 & S.D. dependent var & 1.031824 \\
S.E. of regression & 0.739555 & Akaike info criterion & 2.461465 \\
Sum squared resid & 17.50213 & Schwarz criterion & 2.948062 \\
Log likelihood & -42.15222 & Hannan-Quinn criter. & 2.641918 \\
F-statistic & 4.700238 & Durbin-Watson stat & 2.220848 \\
Prob(F-statistic) & 0.000286 & & \\
\hline \hline
\end{tabular}

variable and not examined in this study include other elements of corporate governance such as the presence of foreign directors, the board of commissioners in terms of their existence, composition, and independence, ownership structure, external auditor independence, industry specialization auditor, auditor change.

\section{Research Discussion}

The discussion each testing variable is explained as follows:

\subsection{The influence of the size of public accounting firm (KAP) on the integrity of financial statement}

The first hypothesis in this study is that the Size of KAP affects the Integrity of Financial Statements. Based on the results of the t test shown in table IV.9 above, KAP size has a t-count of -0.891768 with a significance level of 0.3792 . The results of this test show that the $t$ count value is smaller than $t$ table $(-0.891768<-2.02108)$. If the significance is smaller or equal to $0.05(\leq 0.05)$ then the hypothesis is accepted. The results of this test show a significance value of 0.3792> 0.05; it can be concluded that the first hypothesis of the research $(\mathrm{H} 1)$ is rejected. Based on agency theory, there is a separation between the principal as the owner and agent as the manager who runs the company, the agency conflict will arise. Therefore, to improve the integrity of financial statements, an examination of financial statements is required by an independent-external party, namely the auditor from the Public Accounting Firm (KAP). The results of statistical tests based on the $t$ test presented in table V.1 show that the size of KAP (KAP_SIZE) has no significant effect on the integrity of financial statements. This is indicated by the KAP size significance value of 0.3792 . 
This study has not been able to prove that the size of KAP influences the integrity of financial statements. This is because the measurement using the number of partners in a KAP has not been able to reflect or represent the size of KAP so that it affects the integrity of financial statements. Based on this research data, the auditors are mostly from Large KAP with more than 10 partners. In the concept of large KAP with more than ten partners, management control functions will be better. In some KAPs, there is specific partners who responsible for internal training and research to ensure the quality of the audit which will relate to the integrity of financial statement of their clients.

Mustofa (2014: 313-314) said that when KAPs have many partners but display traditional way of working, then the KAPs cannot be called as big KAPs. The research data shows larger number of partners does not necessarily have larger number of clients The data in the sample shows that there were 0.11 of companies audited by KAP Siddharta \& Widjaja, 0.33 were audited by KAP Tanudiredja, Wibisana \& Rekan, and 0.55 of the companies were audited by KAP Purwantono, Suherman \& Surja. The data shows that KAP Tanudiredja, Wibisana \& Rekan which has larger number of partners in 2012-2016 only comprise of 0.33 of the total sample companies as their audit clients. Moreover, KAP Purwantono, Suherman \& Surja with lesser number of partners posses 0.55 of total sample companies as their audit clients. The results of this study are in line with the research of Qoyyimah, et al (2015), explaining that Standards of profesionnal work of public accountant (SPAP) will be carried out when auditing financial statements. Moreover, level of integrity of financial statements should be a primary responsibility of management.

\subsection{The influence of the size of leverage on the integrity of financial statement}

The second hypothesis in this study is that leverage affects the integrity of financial statements. Based on the results of the t test shown in table 4.9 above, leverage has a t count of -3.333656 with a significance level of 0.0022 . The results of this test show that the calculated $t$ value is greater than $t$ table $(-3,333656>-2,02108)$. The results of this test show a significance value of $0.0022<0.05$; it can be concluded that the second hypothesis of the research is accepted. The results of statistical tests based on the $t$ test presented in table V.1 show that leverage (LEV) has a strong negative and significant effect on the integrity of financial statements. Leverage is the ratio used to measure the extent to which a company's assets are financed by debt. Companies that have a high level of leverage will show that the company also has high financial risk. 
This is because the company is experiencing financial difficulties that can be seen how much debt is used to finance company activities. The data shows that 0.4772 of sample companies with lower leverage relate to higher level of integrity. With the adjusted $R$ square of 0.4862 , it can be concluded that leverage is strong factors that can contribute to the lower level integrity of financial statement. The results of this study supports Fajaryani (2015) and Gayatri and Suputra (2013) who also prove that leverage affect the integrity of financial statements

\subsection{The influence of the size of corporate governance on the integrity of financial statement}

The third hypothesis is corporate governance affects the integrity of financial statements. Based on the T-test results in table 4.9. above, corporate governance has Tvalue of 1.592014 with a significance level of 0.1212 . The results of this test show that the $t$ count value is smaller than $t$ table $(1,592014<2,02108)$. Then it can be concluded that the third hypothesis is rejected, that corporate governance (CG) does not significantly affect the integrity of financial statements. Corporate governance is a system that directs and controls companies to ensure that entities are managed appropriately for the interests of owners who are not in the company and report the economic conditions and performance of the entity appropriately. However, this study has not been able to prove that the assessment assessment by IICG has a significant effect on the integrity of the company's financial statements. The CG scores in this study uses the CGPI index. There are 13 aspects that contribute to the total score. However, of those 13 aspects, no specific financial aspect is being taken into consideration. This explain why in this study CGPI index does not affect the integrity of financial statement. There are financial aspects that can relate to the integrity of financial statement. This research result support Qoyyimah, et al (2015) which also proves that corporate governance does not have a significant effect on the integrity of the company's financial statements.

\section{Conclusion and Reccomendation}

The size of KAP and corporate governance do not have significant effect on the integrity of the financial statements. The quality of audit is strongly based on application of professional standards not based on the size of KAP. Also, in there are other aspects of CG that affect the integrity of financial statement that yet covered in the CGPI index. The study shows that Leverage strongly affect the integrity of the company's financial statements. 
It means the larger assets being financed by debt will negatively affect the integrity of financial statements. Therefore, it is recommended for companies to carefully consider the amount of debt of the company since it might affect the integrity of the financial statements which might also further affect the value of the company.

\section{References}

[1] Arafat, Wilson. (2008). "How to Implement GCG (Good Corporate Governance) Effectively: Mengungkap Horizon 8 Langkah Strategis Membumikan Sistem \& Budaya GCG". Skyrocketing Publisher.

[2] Berk Jonathan \& Peter DeMarzo. (2011). "Corporate Finance”. Second Edition. Pearson.

[3] Dewi, Sari Ni Kadek Harum, I Made Pande D.P. (2016)."Pengaruh Mekanisme Corporate Governanace Terhadap Integritas Laporan Keuangan". E-Jurnal Akuntansi Universitas Udayana Vol.15.3. ISSN: 2302-8556

[4] Dwidinda, Julia. Khairunnisa dan Dedik Nur Triyanto. (2017). "Pengaruh Komisaris Independen, Komite Audit, Kepemilikan Institusional Dan Kepemilikan Manajerial Terhadap Integritas Laporan Keuangan". E-Proceeding of Management: Vol.4, No.3. Telkom University. ISSN: 2355-9357

[5] Ekananda, Mahyus. (2014). “Analisis Ekonometrika Data Panel Bagi Penelitian Ekonomi, Manajemen, Dan Akuntansi”. Edisi Pertama. Jakarta: Mitra Wacana Media.

[6] Fajaryani, Atik. (2015). "Analisis Faktor-Faktor Yang Mempengaruhi Integritas Laporan Keuangan (Studi Empiris Pada Perusahaan Pertambangan Yang Terdaftar Di Bursa Efek Indonesia Periode 2008-2013)". Jurnal Nominal/Volume IV Nomor 1.

[7] Gayatri, Ida Ayu Sri dan I Dewa Gede Dharma Saputra. (2013) "Pengaruh Corporate Governance, Ukuran Perusahaan dan Leverage Terhadap Integritas Laporan Keuangan". E-Jurnal Akuntansi Universitas Udayana 5.2. ISSN: 2302-8556.

[8] Ghozali, Imam. (2013). “Aplikasi Analisis Multivariate Dengan Program IBM SPSS 23”. Edisi 8 Semarang: Badan Penerbit Universitas Diponegoro.

[9] Ghozali, Imam dan Dwi Ratmono. (2013). “Analisis Multivariat dan Ekonometrika Teori, Konsep, dan Aplikasi dengan Eviews 8". Semarang: Badan Penerbit Universitas Diponegoro.

[10] Ikhsan, Arfan dan Herkulanus Bambang Suprasto. (2008). "Teori Akuntansi \& Riset Multiparadigma". Yogyakarta: Graha IImu.

[11] Kieso, D. Weygandt, J. dan Werfield. (2011). “Akuntansi Intermediate”. Edisi Kedua Belas. Jakarta: Penerbit Erlangga. 
[12] Mustofa. (2014). “Manajemen Modern Bisnis Kantor Akuntan”. Jakarta: Kompas.

[13] Nicolin Ocktavia, Arifin Sabeni. (2013). "Pengaruh Struktur Corporate Goveranance, Audit Tenure, Dan Spesialisasi Industri Auditor Terhadap Integritas Laporan Keuangan". Diponegoro Journal of Accounting. ISSN: 2337-3806.

[14] Nurdiniah, Dade dan Endra Pradika. (2017). "Effect of Good Corporate Governanace, KAP Repuatation, Its Size and Leverage on Integrity of Financial Statement". International Journal of Economics and Financial Issues. ISSN: 2146-4138.

[15] Nurjannah, Lita dan Dudi Pratomo. (2014) "Pengaruh Komite Audit, Komisaris Independen Dan Kualitas Audit Terhadap Integritas Laporan Keuangan”. E-Proceeding of Management: Vol.1, No.3. Telkom University. ISSN: 23559357.

[16] Putri, I Gusti Ayu Made Asri Dwija dan I Gusti Ketut Agung Ulupui. (2017). "Pengantar Corporate Governance". Denpasar: CV. Sastra Utama.

[17] Qoyyimah, Sofia Dinil. Masiyah Kholmi dan Gina Harventy. (2015). "Pengaruh Struktur Corporate Goveranance, Audit Tenure Dan Ukuran Kantor Akuntan Publik (KAP) Terhadap Integritas Laporan Keuangan". Jurnal Reviu Akuntansi dan Keuangan Vol.5. ISSN: 2088-0685

[18] Rozania, Ratna Anggraini, Marsellisa Nindito. (2013). "Pengaruh Mekanisme Corporate Governanace, Pergantian Auditor, dan Spesialisasi Industri Auditor Terhadap Integritas Laporan Keuangan". Simposium Nasional Akuntansi XVI. SNA-16

[19] Sarwoko, Iman. (2014). "Pengaruh Ukuran KAP Dan Masa Perikatan Audit Terhadap Penerapan Prosedur Audit Untuk Mendeteksi Risiko Kecurangan Dalam Laporan Keuangan, Serta Implikasinya Terhadap Kualitas Audit (Survei Pada Kantor Akuntan Publik Anggota Forum Akuntan Pasar Modal)". Jurnal Akuntansi/Volume XVIII No. 1. Fakultas Ekonomi Universitas Padjajaran Bandung.

[20] Savitri, Enni. (2016). "Konservatisme Akuntansi Cara Pengukuran, Tinjauan Empiris dan Faktor-Faktor yang Mempengaruhinya". Yogyakarta: Pustaka Sahila Yogyakarta.

[21] Solikhah, Nur Mudasetia. (2017). "Pengaruh Independensi, Mekanisme Corporate Goveranance dan Kualitas Audit Terhadap Integritas Laporan Keuangan". Jurnal Akuntansi Vol.5, No.2. Universitas Sarjanawiyata Tamansiswa. ISSN:2088-768X

[22] Tussiana, Anisa Ayu dan Hexana Sri Lastanti. (2016). "Pengaruh Independensi, Kualitas Audit, Spesialisasi Industri Auditor Dan Corporate Governance Terhadap Integritas Laporan Keuangan". Media Riset Akuntansi, Auditing \& Informasi Vol. 6 No.1. Universitas Trisakti.

[23] Widiatmoko.J, MG. Kentris Indarti, Puji Novia Kurniawati. (2017). “Determinan Integritas Laporan Keuangan (Studi Pada Perusahaan Yang Mengikuti Program Corporate 
Governance Preception Index Tahun 2011-2014)". Prosiding Seminar Nasional Multi Disiplin IImu\&Call for Papers UNISBANK Ket-3. ISBN: 9-789-7936-499-93

[24] Winarno, Wing Wahyu. (2015). "Analisis Ekonometrika dan Statiska dengan Eviews". Edisi 4. Yogyakarta: UPP STMIK YKPN.

[25] Wulandari, Yani N.P dan Ketut Budhiarta. (2014). "Pengaruh Struktur Kepemilikan, Komite Audit, Komisaris Independen Dan Dewan Direksi Terhadap Integritas Laporan Keuangan". E-Jurnal Akuntansi Universitas Udayana 7.3. ISSN: 2302-8556. [26] http://www.idx.co.id

[27] http://www.iaiglobal.or.id 